\title{
Flow Cytometric Analysis of T cell Subset in Bursa of Fabricius in Broiler Chicken (Gallus domesticus)
}

\author{
Jayachandra Kempashi $^{1}$, T.A. Kannan ${ }^{2 *}$, Sabiha Hayath Basha ${ }^{1}$, \\ A. Raja ${ }^{3}$ and Geetha Ramesh $^{1}$ \\ ${ }^{1}$ Department of Veterinary Anatomy, Tamil Nadu Veterinary and Animal Sciences University, \\ Madras Veterinary College, Chennai- 600 007, India \\ ${ }^{2}$ Centre for Stem Cell Research and Regenerative Medicine, Tamil Nadu Veterinary and Animal \\ Sciences University, Madras Veterinary College, Chennai- 600 007, India \\ ${ }^{3}$ Department of Animal biotechnology, Tamil Nadu Veterinary and Animal Sciences University, \\ Madras Veterinary College, Chennai- 600 007, India
}

*Corresponding author

\section{A B S T R A C T}

\section{Keywords}

Bursa of fabricius, T cell subset, Nandanam chicken, Flowcytometric analysis.

Article Info

Accepted:

24 January 2017

Available Online:

10 February 2017
Bursa of Fabricius, the primary lymphoid organ for B-lymphopoiesis in Avian species and is responsible for humoral immunity. Flow cytometric analysis of $\mathrm{Bu}-1 \mathrm{a}+\mathrm{B}$-cell count and CD3+, CD4+ and CD8+ T-cell count were conducted in bursa of Fabricius of four different age groups of Nandanam broiler chicken viz., day-old, two, four and six weeks. Twelve birds from each age group, from both vaccinated and non-vaccinated groups were utilised. Tissue samples of the bursa were collected aseptically and processed for flow cytometric studies using monoclonal antibodies. Mean Bu-1a+, CD3+ and CD4+ cell count was highest in four week-old birds and lowest in day-old birds, whereas CD8+ cell count was highest in four week-old birds and lowest in six week-old birds in nonvaccinated group. In vaccinated group, $\mathrm{Bu}-1 \mathrm{a}+$ cell count was highest in two week-old and lowest in six week-old birds. The mean CD3+ and CD4+ cell count was highest in four week-old birds and lowest in two week-old birds, whereas CD8+ cell count was highest in four week-old and lowest in six week-old birds in vaccinated group.

\section{Introduction}

In India, poultry sector has undergone a tremendous growth during the last few decades. The broiler production is growing at the rate of nearly 8-10 percent every year and growth in production of poultry/chicken meat increased as per data collected under Integrated Sample Survey Scheme (Shukla and Sujit, 2010).
All living beings manage not only to survive but indeed thrive in potentially hostile milieu, without seeming effort. This freedom from disease is depends on the existence of a complex and highly sophisticated defense system, called lymphatic system (Cortan, 1988; Khan et al., 2014 and Kannan et al., 2015). 
Unlike other vertebrates, avian species have two discrete primary lymphoid organs, the thymus in which T-lymphocytes develop and responsible for cell mediated immunity (CMI) and the bursa of fabricius, the primary site for B-lymphopoiesis which is responsible for humoral immunity (HI) (Glick et al., 1956 and Warner, 1967). The bursa of fabricius in chicken is located at the dorsal portion of cloaca and connects with the cloaca by the bursal duct at its junction with the colon (Glick, 1964).

The chicken is a foundational model for immunological research and continues to be a valuable animal model for insights into immune function. In particular, the development of B cells in this unique organ, the bursa of fabricius, has provided a novel opportunity to study B cell development. Although chicken generate their immunoglobulin (Ig) repertoire in a different way than mice and humans, there are many striking similarities in the developmental process. In particular, the control of lymphocyte migration and survival is a key to the development of an immune system. The evolutionary distance of chicken and mammals underscore how common the problems are as well as how the solutions are often similar. Such commonalities serve to maintain the chicken as a compelling animal to study B cell development (Funk and Thompson, 1996).

It has been recognized that the bursa also functions as a peripheral gut-associated lymphoid organ. Antigens presented via the cloaca and bursal lumen can stimulate specific antibody production by bursal lymphocytes (Lupetti et al., 1984). Thus, the bursa plays a role in local gut immunologic defense.

Commercial production of broiler and layer flock is dependent on the immunological status of the birds. Genetically determined immunocompetence and environmental factors are responsible for varying susceptibility or resistance to infectious diseases of chicken (Bridle et al., 2006).

Little is known about the age related immunocompetence in commercially raised broiler chicken with their individual management programmes and specific immunization protocols. Therefore, understanding the age related immunocompetence by evaluating $\mathrm{T}$ and $\mathrm{B}$ lymphocyte population in apparently healthy commercially raised chicken is of direct relevance to develop breeding strategies as well as promoting health measures of the flock.

Nandanam chicken is a dual purpose, colored variety with good disease resistance and most popular among poultry farmers due to its adaptability to backyard farming. This strain was developed in Institute of Poultry Production and Management, Tamil Nadu Veterinary and Animal Sciences University, Chennai. Hence, an attempt has been made to explore flowcytometric evaluation of CD-3+, CD-4+, CD-8+ and Bu-1a+ cell count in bursa of fabricius in Nandanam chicken of different age groups.

\section{Materials and Methods}

Bursal tissue samples required for the study were collected from four different age groups viz., day-old, two, four and six weeks. Twelve birds each were utilised in each age group. Vaccinated and non-vaccinated birds were procured from Institute of Poultry Production and Management, Tamil Nadu Veterinary and Animal Sciences University, Chennai. The birds were maintained in a healthy environment, properly vaccinated as per the schedule presented in table 1 and did not show any signs of disease. The birds were 
euthanized by high cervical dislocation and bursa of fabricius was removed for phenotypic analysis of lymphocytes.

To evaluate the lymphocyte populations, single cell suspensions were prepared by finely mincing the bursal tissue and filter it through 60 micron filters (Wu et al., 2000) and the cell concentration was adjusted to 1.5 x $10^{6}$ cells $/ \mathrm{ml}$ in Rose Park Memorial Institute (RPMI)-1640 medium. Then the cells were stained by a single colour immunostaining procedure using a panel of monoclonal antibodies (mAb) as per Chan et al., (1988). Panel of mAb used el were presented in table 2. Statistical analysis was carried out using statistical analysis software (Systat Inc., Evanston, IL). Test results were considered significant of $\mathrm{P}<0.01$. All data were expressed as the mean \pm S.E.

\section{Results and Discussion}

In the present study, flow cytometric analysis of $\mathrm{Bu}-1 \mathrm{a}+, \mathrm{CD} 3+, \mathrm{CD} 4+$ and CD8+ lymphocyte counts were recorded in the bursa of Fabricius of both vaccinated and nonvaccinated birds in different age groups. The mean percentage of $\mathrm{Bu}-1 \mathrm{a}+, \mathrm{CD} 3+, \mathrm{CD} 4+$ and CD8+ cell counts in vaccinated and non vaccinated birds were presented in tables 3 and 4.

In the non-vaccinated group, the mean percentage of $\mathrm{Bu}-1 \mathrm{a}+$ cell count was lowest in day-old birds. As age advances, Bu-1a+ cell count also increased up to four week of age and thereafter there was a decline in the cell count. Statistically, the results showed significant difference between day-old, two week and four week-old birds but there was no significant difference in $\mathrm{Bu}-1 \mathrm{a}+$ cell count between four week and six week-old birds as reported by Asheg et al., (2003) in White Plymouth Rock chicken. In all the age groups studied, Bu-1a+ cell count was more than
CD3+, CD4+ and CD8+ cell count indicative of the major cell population in the bursa are $\mathrm{B}$ lymphocytes than CD3+, CD4+ and CD8+ T cells. This is in total agreement with the findings of Chan et al., (1988) and Khan and Hashimoto (1996) who reported that the bursal follicles consisted of 85-95 percent B lymphocytes, 4 percent of $\mathrm{T}$ cells and other non lymphoid cells.

The mean Bu-1a, CD3 and CD4 positive cell count was highest in four week-old birds and lowest in day-old birds, whereas CD4 positive cell count was highest in four week-old birds and lowest in six week-old birds in nonvaccinated group. In contrary to this Asheg et al., (2003) reported that in White Plymouth Rock chicken the Bulb+ cell count was highest in four week-old birds and lowest in two week-old birds. CD3+ cell count was highest in two week-old birds and lowest in seven day-old birds. CD4+ cell count was highest in two week-old birds and lowest in four week-old birds and CD8+ cell count was highest in three week-old birds and lowest in four week-old birds.

In vaccinated group, $\mathrm{Bu}-1 \mathrm{a}+$ cell count was highest in two week-old and lowest in six week-old birds. This was in total agreement with Castro et al., (2009) who stated that Infectious Bursal Disease (IBD) vaccination using intermediate plus vaccine strain can cause moderate to severe damage to the bursal tissue (B cell depletion) ten days post vaccination and after forty two days of vaccination there was a sign of bursal restoration represented by repopulation of the follicles.

The mean CD3+ and CD4+ cell count was highest in four week-old birds and lowest in two week-old birds, whereas CD8+ cell count was highest in four week-old and lowest in six week-old birds in vaccinated group. The CD4:CD8 was highest in day-old birds and 
lowest in two week-old birds in nonvaccinated birds, whereas Asheg et al., (2003) recorded highest CD4:CD8 in seven day-old birds and lowest in 21 day-old birds. In vaccinated group, CD4:CD8 was highest in six week-old birds and lowest in two weekold birds. As reported by Cheng et al., (2001) in White Leghorn chickens, the blood CD4+ to $\mathrm{CD} 8+\mathrm{T}$-cells has been used as an indicator of CMI (Cell Mediated Immunity) response. $\mathrm{He}$ also reported that the normal ratio of CD4+ to CD8+ T-cells should be greater than 1.5:1 otherwise, cellular mediated responses and survivability were greatly damaged.

Table.1 Vaccination schedule followed in the experiment

\begin{tabular}{|l|l|}
\hline $7^{\text {th }}$ day-NDV (F1 strain) & one drop i/o \\
\hline $14^{\text {th }}$ day-IBD (Intermediate Georgia strain) & one drop i/o \\
\hline $26^{\text {th }}$ day-NDV (Lasota) & one drop i/o \\
\hline
\end{tabular}

Table.2 Monoclonal antibodies used

\begin{tabular}{|l|c|c|c|}
\hline \multicolumn{1}{|c|}{ Specificity } & MAbs & Isotype & Dilution \\
\hline $\begin{array}{l}\text { CD3 } \\
\text { (Mouse Anti-Chicken CD3) }\end{array}$ & Cat.\# MCA1473 & $\operatorname{IgG1}$ & $1: 10$ \\
\hline $\begin{array}{l}\text { CD4 } \\
\text { (Mouse Anti-Chicken CD4) }\end{array}$ & Cat.\# MCA2164 & $\operatorname{IgG2b}$ & $1: 10$ \\
\hline $\begin{array}{l}\text { CD8 } \\
\text { (Mouse Anti-Chicken CD8) }\end{array}$ & Cat.\# MCA2166 & $\operatorname{IgG1}$ & $1: 10$ \\
\hline $\begin{array}{l}\text { Bu-1a* Anti-Chicken Bu-1a) } \\
\text { (Mouse Ant Antibody, (Goat Anti- }\end{array}$ & Cat.\# SC-70447 & $\operatorname{IgG1}$ & $1: 10$ \\
\hline $\begin{array}{l}\text { Secondary IgG (H/L), FITC } \\
\text { Mouse Cat.\# STAR117F } \\
\text { Conjugated) }\end{array}$ & Polyclonal & $1: 50$ \\
\hline
\end{tabular}

*Antibody procured by Santa cruz Biotechnology, Inc, Europe. Remaining all antibodies were procured from AbD Serotec, UK.

Table.3 Mean Bu-1a+, CD3+, CD4+ and CD8+ cell counts in different age groups of nonvaccinated birds

\begin{tabular}{|c|c|c|c|c|c|c|}
\hline \multirow[b]{2}{*}{ Cell Type } & \multicolumn{4}{|c|}{ Age groups } & \multirow[b]{2}{*}{$\begin{array}{c}F \\
\text { Value }\end{array}$} & \multirow[b]{2}{*}{ Significance } \\
\hline & Day-old & $\begin{array}{l}\text { Two week- } \\
\text { old }\end{array}$ & $\begin{array}{c}\text { Four week- } \\
\text { old }\end{array}$ & $\begin{array}{l}\text { Six week- } \\
\text { old }\end{array}$ & & \\
\hline Bu-1a & $48.80 \pm 4.06^{\mathrm{c}}$ & $64.28 \pm 6.69^{b}$ & $88.51 \pm 3.92^{\mathrm{a}}$ & $83.27 \pm 1.07^{\mathrm{a}}$ & 17.046 & * \\
\hline CD3 & $12.36 \pm 0.75^{b}$ & $22.04 \pm 4.25^{\mathrm{ab}}$ & $29.55 \pm 4.07^{\mathrm{a}}$ & $14.21 \pm 1.99^{b}$ & 6.338 & * \\
\hline CD4 & $13.56 \pm 1.55^{b}$ & $23.70 \pm 4.64^{\mathrm{ab}}$ & $26.04 \pm 4.32^{\mathrm{a}}$ & $13.42 \pm 1.58^{b}$ & 3.768 & * \\
\hline CD8 & $13.59 \pm 2.16^{b}$ & $27.54 \pm 5.87^{\mathrm{ab}}$ & $29.37 \pm 7.25^{\mathrm{a}}$ & $14.78 \pm 1.85^{\mathrm{ab}}$ & 2.881 & * \\
\hline CD4:CD8 & $1.10 \pm 0.14^{\mathrm{a}}$ & $0.87 \pm 0.03^{\mathrm{a}}$ & $1.05 \pm 0.17^{\mathrm{a}}$ & $0.92 \pm 0.05^{\mathrm{a}}$ & .867 & NS \\
\hline
\end{tabular}


Table.4 Mean Bu-1a+, CD3+, CD4+ and CD8+ cell counts in different age groups of vaccinated birds

\begin{tabular}{|c|c|c|c|c|c|c|}
\hline \multirow{2}{*}{ Cell Type } & \multicolumn{4}{|c|}{ Age groups } & \multirow{2}{*}{$\begin{array}{c}F \\
\text { value }\end{array}$} & \multirow{2}{*}{ Significance } \\
\hline & Day-old & Two week-old & Four week-old & Six week-old & & \\
\hline Bu-1a & & $93.63 \pm 1.90^{\mathrm{a}}$ & $77.60 \pm 10.60^{\mathrm{ab}}$ & $56.94 \pm 10.10^{\mathrm{b}}$ & 4.651 & * \\
\hline CD3 & - & $15.32 \pm 1.41^{\mathbf{b}}$ & $26.54 \pm 2.94^{\mathrm{a}}$ & $18.71 \pm 1.32^{\mathrm{b}}$ & 7.987 & $*$ \\
\hline CD4 & - & $16.80 \pm 0.87^{\mathrm{b}}$ & $25.42 \pm 2.72^{\mathrm{a}}$ & $20.33 \pm 2.47^{\mathrm{ab}}$ & 3.932 & * \\
\hline CD8 & - & $14.52 \pm 1.61^{\mathrm{a}}$ & $20.76 \pm 2.90^{\mathrm{a}}$ & $14.51 \pm 1.33^{\mathrm{a}}$ & 3.050 & NS \\
\hline CD4:CD8 & - & $1.20 \pm 0.09^{\mathrm{a}}$ & $1.31 \pm 0.15^{\mathrm{a}}$ & $1.43 \pm 0.20^{\mathrm{a}}$ & 0.505 & NS \\
\hline
\end{tabular}

CD4+: CD8+ T-cells in blood serves to estimate lymphocyte function. An elevated CD4 count implies increased lymphocyte reactivity because helper cells predominate, where as high CD8 count implies depressed lymphocyte reactivity.

In all age groups studied, CD8+ cell count was more when compared to CD4+ cell count in non-vaccinated birds, whereas CD4+ cell count were more when compared to CD8+ cells in vaccinated birds, this was in accordance with Tizard (2000) who reported that, CD4 is found only on T particularly the $\mathrm{T}$ helper cells that recognizes processed exogenous antigen. CD4 is a receptor for MHC-II molecules.

In contrast, CD8 is only found in T cells that attack and kill abnormal cells i.e. cytotoxic $\mathrm{T}$ cells. CD8 is also a receptor for MHC- class I molecules and is required for the reorganization of processed endogenous antigen.

\section{Acknowledgement}

The authors are thankful to the Dean, Madras Veterinary College and Tamil Nadu Veterinary and Animal Sciences University, India for providing facilities to carry out this work.

\section{References}

Asheg, A.A., Levkut, M., Revajova, V., Evaikova, Z., Kolodzieyski, L., and Pistl, J. 2003. Dynamics of lymphocyte subpopulations in immune organs of chickens infected with Salmonella enteritidis. Acta. vet. Brn., 72: 359-364.

Bridle, B.W., R. Julian, P.E. Shewen, J.P. Vaillancourt and A.K. Kaushik. 2006. T-lymphocyte subpopulations diverge in commercially raised chickens. Can. J. Vet. Res., 70: 183-190.

Castro, M., Saume, E., Díaz, C., García, J. and Perozo, F. 2009. Bursal restoration after intermediate and intermediate plus infectious bursal disease virus vaccination. Revista Científica, 19(2): 119-123.

Chan, M.M., Chen, C.H., Ager, L.L. and Cooper, M.D. 1988. Identification of the avian homologues of mammalian CD4 and CD8 antigens. J. Immunol., 140 (7): 2133-2138.

Cheng, H.W., Eicher, S.D. Chen, Y., Singleton, P. and Muir, W.M. 2001. Effect of genetic selection for group productivity and longevity on immunological and hematological parameters of chickens. Poult. Sci., 80: 1079-1086. 
Cortan, R.S., Kumar, V., Robbin, SL.. 1998. Robbin's Pathogenic Basis of Disease. 4th ed. Philadelphia: W.B. Saunders; 163-4.

Funk, P.E. and Thompson, C.B. 1996. Current concepts in chicken B cell development. Curr. Top. Microbiol. Immunol., 212: 17-28.

Glick, B. 1964. Historical perspective: The bursa of Fabricius and its influence on B-cell development, past and present. Vet. Immunol. Immunopathol., 30(1): 3-12.

Glick, B., Chang, T.S. and Jaap, R.G. 1956. The bursa of Fabricius and antibody production. Poult. Sci., 35: 224-225.

Kannan, T.A., Geetha Ramesh, Ushakumari, S., Dhinakarraj, G., and Vairamuthu, S. 2015. Thymic Hassall's corpuscles in Nandanam chicken - light and electronmicroscopic perspective (Gallus domesticus). J. Animal Sci. Technol., 57: 30.

Khan, M.Z.I., Masum, A,. Khan, M.Z.I., Aziz, A.R.B., Nasrin, M., Siddiqi, M.N.H., et al. 2014. Histomorphology of the Lymphoid Tissues of Broiler Chickens in Kelantan, Malaysia. Sains Malaysiana. 43(8): 1175-9.

Khan, M.Z.I. and Hashimoto, Y. 1996. An immunohistochemical analysis of $\mathrm{T}$ - cell subsets in bursa of Fabricius during postnatal development. J. Vet. Med. Sci., 58(12): 1231-1234.

Lupetti, M., Dolfi A., Malatesta, T. and Michelucci, S. 1984. A contribution to the study of the regulatory system of local immune response in "Gallus domesticus." Dev. Comp. Immunol., 8: 663.

Shukla, P.K. and Sujit, N. 2010. Future prospects for alternative poultry farming systems in India. Presented in National seminar on emerging opportunities in alternative poultry farming systems, 11-28.

Tizard, I.R. 2000. Vet. Immunol., An introduction. $7^{\text {th }}$ edition, Elsevier, USA., pp-93.

Warner, N.L. 1967. Immunological role of avian thymus and bursa of Fabricius. Folia. Biol., 13: 1-17.

Wu, C.C., Dorairajan, T. and Linn, T.L. 2000. Effect of ascorbic acid supplementation on the immune response of chickens vaccinated and challenged with IBD virus. Vet. Immunol. Immunopathol., 74: 145 152.

\section{How to cite this article:}

Jayachandra Kempashi, T.A. Kannan, Sabiha Hayath Basha, A. Raja and Geetha Ramesh. 2017. Flow Cytometric Analysis of T cell Subset in Bursa of Fabricius in Broiler Chicken (Gallus domesticus). Int.J.Curr.Microbiol.App.Sci. 6(2): 1534-1539. doi: http://dx.doi.org/10.20546/ijcmas.2017.602.171 